\title{
Structuring China's Engagement with International Human Rights: the case of wage protection law and practice*
}

Sarah Biddulph

Law School,

The University of Melbourne

\section{Introduction}

This year marks the $10^{\text {th }}$ anniversary of China's accession to the WTO. That period has seen dramatic reforms in China's economy and increases in the breadth and depth of China's engagement with the international trading order. Many have given a positive evaluation of China's engagement with the international trading regime, in particular citing a high level of responsiveness to rulings of the dispute resolution panel decisions (Harpaz). Yet in some areas, China seems to have resisted and even rebuffed international norms and conventions. Whilst China has been an active participant in the ILO, it has never indicated any intention to ratify the conventions on collective bargaining and freedom of association, which comprise two of the eight core conventions set out in the 1998 Declaration on Fundamental Principles and Rights at Work. In her excellent study of China's process of engagement with and socialization into the international order, Ann Kent has noted that the Chinese state's willingness to adopt reforms that would bring it into greater conformity with international labour regime ceases where to do so is considered to be a 'threat to the existing political system' (Kent, 2007). This has certainly been the case with the continuing prohibition on establishment of independent trade unions and, by extension, collective bargaining.

This chapter develops the theme of this book on modes of domestic engagement with international trade and human rights norms, and the difficulty in practice of creating links between these two bodies of rules. It does so through an evaluation of the tentative reforms to collective bargaining in China. Whilst the Chinese have for many years had strong engagement with the ILO and have implemented regulatory structures that are largely consistent with ILO principles, it has not done so in its treatment of the rights to form independent unions and to engage in collective bargaining. Collective bargaining is emblematic both of the practical interconnectedness of international trade and rights regimes, and of China's failure to engage with international standards where it is contrary to the state's fundamental political values. For this reason some argue that without fundamental reform of China's political system, there can be no prospect for meaningful reforms to the structure and orientation of China's trade unions or to collective bargaining.

Yet in recent years collective bargaining has become a hot topic within China. A number of local reforms, notably in Zhejiang and Guangdong, have been the subject of intensive scrutiny and debate. These debates have also inevitably touched upon the related issues of how to reform China's trade unions so that they better represent the interests of workers, and how to view and deal with strikes which are becoming increasingly prevalent. This paper examines recent tentative reforms to systems of collective consultation over wages and conditions as one of the policy responses to labour unrest. It considers the extent to which these debates and proposed reforms reveal some domestic policy space which might enable reforms to be adopted or considered that are more consistent with international labour norms. 
Following the description employed by Labonte in this volume, in referring to policy space I mean 'the freedom, scope, and mechanisms that governments have to choose, design and implement public policies to fulfill their aims'. It also includes the opportunities for interest groups and individuals to have inputs into the processes of government formulation of these mechanisms. An examination of this policy space necessarily entails a consideration of the aims of the Chinese government in permitting, even encouraging, local experimentation with changes to existing forms of collective consultation. It requires a consideration of the extent to which the limited reforms of the type discussed in this paper may be able to contribute to realization of those goals. In China, policy space is often highly contested and seldom completely dominated by the central government, or the central Party apparatus. As this chapter documents, the mechanisms ultimately employed to address social issues often develop in a piecemeal fashion after periods of trial and error. Successful local experiments may not be suitable for application to the country as whole. As this chapter also demonstrates, it is important not to overstate the intentionality of state policy making. Some reforms might evolve in response to a range of interconnected problems, and a range of different policies and mechanisms, not all mutually consistent, may be developed or adapted to address a particularly acute problem.

Part 2 examines international norms of collective bargaining and the limits to China's engagement with the ILO on this topic. Part 3 examines the background economic and industrial situation in China that has reinvigorated discussions about the potential for renovated forms of collective bargaining to play a role in industrial policy. It argues that the primary driver for reform is the state's urgent desire to stem the growth of industrial unrest, with the consequence that the primary objective of these tentative reforms is to promote stability. Part 4 evaluates these reforms and reform proposals. This chapter concludes that whilst there is domestic policy space for reform, the public policy objective of limiting industrial disputation constrains both the nature and extent of the reforms. Experiments with collective bargaining are thus bounded within existing political orthodoxies about the position and role of China's unions and accepted modes of regulation which favour coordinated administrative approaches led by Party and government agencies. Within these parameters, reforms have in some cases bypassed enterprise unions by removing collective consultations to higher level unions, or have sought to strengthen workers' direct voice in consultations. The inability or unwillingness to engage in fundamental reform of China's unions remains a barrier to moving toward a model of industrial relations that empowers workers to demand justice in their own terms. Instead it retains a state-centred model of industrial relations where unions, government agencies and Party organs seek to dominate processes of collective consultation and to determine ultimately, what standards constitute the common welfare and social justice. The likely outcome is that reform of collective consultation may improve mechanisms by which wages and conditions may be negotiated periodically, but they are unlikely to extend as far as promoting industrial democracy as understood at the international level.

\section{Linking trade and labour at the international level: China's engagement with the ILO on collective bargaining}

At a practical level it is perfectly apparent that labour standards in any particular country have a direct impact on the terms of international trade. This is especially true for countries such as China which has relied on exports as one of its primary mechanisms for economic growth. China's heavy reliance on low 
cost exports to drive its economic growth has been made possible in part at least by the low cost of labour (Friedman and Lee, 2010: 507, Sharma, June 20, 2010). In fact, China has been identified as the country against which many other economies of the south compete for exports to countries of the north, with the risk of precipitating a 'race to the bottom' (Chan and Ross, 2003). Many countries have adopted a range of strategies to protect themselves against erosion of their export markets in the face of competition from China (Berik and van der Meulen Rodgers, January 2008).

However, at the level of international rules, no such connection exists. The countries of the south have been unwilling to link core labour standards with international trading rules, arguing that inclusion of a social clause in the WTO agreements is inherently protectionist and designed to deprive low wage countries of their comparative advantage (WTO Ministerial Conference, 2001). Instead of including a social clause in the WTO agreements, the first WTO Ministerial Conference in Singapore in 1996 affirmed the ILO as the primary agency with responsibility for promoting observance of 'internationally recognized core labour standards'.. ${ }^{1}$

These internationally recognized core labour standards were articulated by the ILO in June 1998 with adoption of the Declaration on Fundamental Principles and Rights at Work (the 'Declaration'). These core labour standards comprise:

- Freedom of association ${ }^{2}$ and the effective recognition of the right to collective bargaining; ${ }^{3}$

- Elimination of all forms of forced or compulsory labour; ${ }^{4}$

- Effective abolition of child labour; ${ }^{5}$. and

- Elimination of discrimination in respect of employment and occupation. ${ }^{6}$

The effective right to collective bargaining has been identified as a core means of promoting the common welfare and achieving social justice; the basic objective of the ILO. It is premised on 'free discussion' and 'democratic decision' between the representatives of workers and employers who enjoy equal status with governments.. ${ }^{7}$ The right of labour to associate freely and engage in collective

\footnotetext{
${ }^{1}$ Ministerial Declaration of the first WTO Ministerial Conference accessed at http://www.ilo.org/declaration/lang-en/index.htm

${ }^{2}$ Convention 87; the Convention on Freedom of Association and Protection of the Right to Organise, 1948 http://www.ilo.org/ilolex/cgi-lex/convde.pl?C087

${ }^{3}$ Convention 98; the Convention on the Application of the Principles of the Right to Organise and to Bargain Collectively, 1949 http://www.ilo.org/ilolex/cgi-lex/convde.pl?C098

${ }^{4}$ Convention 29, the Convention on Forced or Compulsory Labour 1930 http://www.ilo.org/ilolex/cgilex/convde.pl?C029 , Convention 105, the Convention on Abolition of Forced Labour 1957 http://www.ilo.org/ilolex/cgi-lex/convde.pl?C105

${ }^{5}$ Convention 138, the Convention on the Minimum Age for Admission to Employment, http:/www.ilo.org/ilolex/cgi-lex/convde.pl?C138 ratified by China in 1999, Convention 182, the Convention on the Prohibition and Immediate Action for the Elimination of the Worst Forms of Child Labour, 1999 http://www.ilo.org/ilolex/cgi-lex/convde.pl?C182 ratified by China in 2002

${ }^{6}$ Convention 100, the Convention on Equal Remuneration for Men and Women Workers for Work of Equal Value, 1951 http://www.ilo.org/ilolex/cgi-lex/convde.pl?C100 ratified by China in 1990, Convention 111, Convention on Discrimination in Respect of Employment and Occupation 1958 http://www.ilo.org/ilolex/cgi-lex/convde.pl?C111 ratified by China in 2006, Dates of ratification are set out at http://www.ilo.org/declaration/followup/annualreview/ratificationstatus/lang--en/index.htm

${ }^{7}$ Declaration of Philadelphia 1944 Paragraph I(d) "fundamental principles on which the Organization is based”
} 
bargaining has repeatedly been articulated as a core value of the ILO. ${ }^{8}$. It is based on the idea that labour must have the power to organize freely and be able to take industrial action in support of bargaining over wages and conditions (Lieberwitz, 2006: 641-653).

China has argued that it is not bound by the conventions on freedom of association and collective bargaining ${ }^{9}$ as it has not ratified them. ${ }^{10}$. However, the intention of the Declaration was to commit all the ILO member states to this list of core labour standards regardless of whether or not they had ratified the relevant conventions (Alston, 2004: 460). The ILO's position is that ILO members have agreed to 'respect and promote' these core conventions even if they have not ratified them. It states that 'the ILO Declaration on Fundamental Principles and Rights at Work is an expression of commitment by governments, employers' and workers' organizations to uphold basic human values - values that are vital to our social and economic lives'. ${ }^{11}$

The debate about the binding nature of these conventions must also be understood in light of the ILO's lack of strongly punitive mechanisms to enforce compliance. It relies instead primarily on soft law mechanisms of supervision, peer pressure and assistance to promote compliance. ${ }^{12}$. China has in practice engaged with the ILO in respect of the right to collective bargaining and freedom of association through a number of its mechanisms. The Follow-up mechanism to the Declaration, for example, has focused on encouraging progress toward ratification of these Conventions by asking countries to provide an annual report on domestic treatment of the rights contained in the Conventions that they have not yet ratified. ${ }^{13}$. In respect of freedom of association, the ILO's Committee on Freedom of Association has

${ }^{8}$ ILO Declaration of Fundamental Principles and Rights at Work 1998, ILO Declaration on Social Justice for a Fair Globalization 2008

${ }^{9}$ Country baselines under the ILO Declaration Annual Review (2000-2010): Freedom of Association and the Right to Collective Bargaining (FACB) accessed at http://www.ilo.org/wcmsp5/groups/public/---ed_norm/---

declaration/documents/publication/wcms_091262.pdf

${ }^{10}$ Nor has it ratified the conventions on elimination of all forms of forced or compulsory labour; Conventions 29 and 105. Country baselines under the ILO Declaration Annual Review (2000-2010): the Elimination of All Forms of Forced or Compulsory Labour (FL), accessed at http://www.ilo.org/wcmsp5/groups/public/---ed_norm/--declaration/documents/publication/wcms_091264.pdf

${ }^{11} \mathrm{http}: / / \mathrm{www} . \mathrm{ilo.org} /$ declaration/lang--en/index.htm Another argument is that China is bound to these principles through being a party to the UDHR, which at article 23 provides for core labour protections: (1) Everyone has the right to work, to free choice of employment, to just and favourable conditions of work and to protection against unemployment. (2) Everyone, without any discrimination, has the right to equal pay for equal work. (3) Everyone who works has the right to just and favourable remuneration ensuring for himself and his family an existence worthy of human dignity, and supplemented, if necessary, by other means of social protection. (4) Everyone has the right to form and to join trade unions for the protection of his interests. Accessed at http://www.un.org/en/documents/udhr/ ${ }^{12}$ Apart from the reporting and review mechanisms, the ILO supervises compliance through its processes for responding to complaints. ILO Constitution article 22 and 19 in respect of reporting and article 24 in respect of complaints. Countries are required to report on their actions to promote compliance with the core labour conventions that they have not ratified. Elliott, 2000 http://www.iie.com/publications/pb/pb00-6.pdf Where a convention has been ratified, monitoring of compliance by the ILO's Committee of Experts on the Application of Conventions and Recommendations goes only so far as to consider whether the legal system complies with the convention. Cooney, 1999, 377. A complaint made under ILO Constitution article 26 about gross violations of a convention to which the country has acceded, may, if the country refuses to act on recommendations to rectify the problem article 33 provides the 'Governing Body may recommend to the Conference such action as it may deem wise and expedient to secure compliance therewith'.

${ }^{13}$ ILO 'The Declaration’ accessed at http://www.ilo.org/declaration/thedeclaration/lang--en/index.htm 
effectively exercised jurisdiction to monitor all member states' compliance with freedom of association and collective bargaining conventions, including China. A number of cases against China have been brought before the committee. Despite protestations that it was not bound, before long China did, even if reluctantly, provide information in response to complaints lodged against it.. ${ }^{14}$.

But, despite active engagement with the ILO in many other areas, ${ }_{-15}^{15}$ China has not indicated any willingness to change its fundamental stance on collective bargaining and freedom of association. In February 2001, China ratified the International Covenant on Economic, Social and Cultural Rights (ICESCR) and again refused to recognise the right of workers to join independent unions of their own choosing. When ratifying the ICESCR in February 2001 China announced a reservation to the right to establish and join workers' organisations of one's own choosing under article 8. China declared that the right to join a trade union would be dealt in accordance with Chinese law, more particularly the Constitution of the People's Republic of China, Trade Union Law of the People's Republic of China and Labour Law of the People's Republic of China. Both the Trade Union Law and the ACFTU Charter emphasise the leadership of the Communist Party of China over the union movement. ${ }^{16}$. Unions are required to 'assist people's governments in conducting their work and shall uphold the socialist state political power of people's democratic dictatorship'.. ${ }^{17}$

\section{Domestic practice and reforms}

In light of this stance internationally, it is interesting to examine more closely domestic practices of collective contracting and recent debates arguing the need for significant changes both to the role and responsibilities of China's unions and to the system of collective contracting. To provide context for this discussion, it is first necessary to sketch a brief overview of the current issues facing regulation of the labour market and the nature of collective contracting.

\subsection{Collective bargaining in China: contrasts with international standards}

China's labour market has undergone dramatic transformation since the mid 1980s when the first steps were taken to move away from an administrative system of allocation of urban workers to State-owned enterprises, to a more market based labour contract system. The PRC Labour Law codified a regime of labour regulation governed primarily by individual labour contracts, supplemented by a system of collective contracts (Biddulph and Cooney, 1994: 254-8). Collective contracts were to be negotiated and signed by the enterprise union and the employer. The All China Federation of Trade Unions ('ACFTU') has actively sought to expand coverage of collective contracts, though has required the assistance of a

\footnotetext{
${ }^{14}$ Kent, 2007: 185, 190-192, discussing China's responses to cases brought by the ICFTU against China, Cases 1500 and 1652, after the crack down on independent unions during and after the 1989 Tiananmen Square massacre.

${ }^{15}$ At December 2010, China had ratified 25 Conventions with 22 of those in force, including four of the eight Fundamental Conventions. It has submitted all of the requested reports on application of the ratified conventions. International Labour Conference $100^{\text {th }}$ Session 2011, Information Document on Ratifications and Standards Related Activities accessed at http://www.ilo.org/wcmsp5/groups/public/---ed_norm/---

relconf/documents/meetingdocument/wcms_151865.pdf

${ }^{16}$ The Trade Union Law article 4 reiterates amongst other things, leadership of the Communist Party and union focus on economic construction.

${ }^{17}$ Trade Union Law article 5
} 
range of state and Party agencies to achieve this goal. ${ }^{18}$. China ratified ILO Convention 144 in 1990 and established a system of tripartite consultation. ${ }^{19}$. Since establishment of the tripartite meeting system in 2001, expanding the scope of collective contracts has been a main priority (Chen, 2010: 107, Clarke et al., 2004: 240). According to the press release issued after the $15^{\text {th }}$. National Congress of Trade Unions held in October 2008, more than 140 million Chinese workers were then covered by a collective contract ( $\mathrm{Li}$, 7 October 2008, IHLO, February 2009). It is reported that by the end of 2010, employees have entered into labour contracts in over $97 \%$ of national level enterprises and $65 \%$ of small scale enterprises (Anonymous, 30 December 2010). Whilst these numbers look impressive, collective contracts have been far from effective as a vehicle for interest negotiations at the enterprise level. In practice top-down administrative mechanisms such as quotas and instructions issued by the Party, government and higher level union organizations have been used to ensure the expanded reach of collective contracts. ${ }^{20}$. As a result, many only reflect the minimum legal standards without the parties engaging in any form of bargaining over wages and conditions (Clarke et al., 2004: 249-250). A fundamental problem rests with the enterprise union, with the union head often also being appointed by and having a role in enterprise management. These unions are neither able nor motivated to represent the interests of workers in negotiations, particularly if these interests conflict with Party or government policy, or enterprise interest (Chen, 2010: 107-8, Clarke et al., 2004: 242, Liu, 2010: 35-6). In fact, many enterprise unions are the last to find out about strikes or other forms of industrial action, and then seek to mediate between the workers and management to secure a return to work. Seldom do they see their role as acting on behalf of workers and promoting their claims (Chen, 2010).

There is a huge distance between Chinese systems of collective consultation and a system of collective bargaining embodied in the ILO Conventions which contemplate 'free and voluntary negotiations' between independent representatives of both workers and employers to 'set wages and conditions of work' and the 'rules governing their relationship' (ILO, 2010). Whilst part of the problem is that union representatives form part of enterprise management, the fundamental problem lies with relationship between the union movement and the Chinese Communist Party ('CCP' or 'Party'). Rather than simply representing workers' interests, China's unions fulfill the important role of providing a link between the Party and workers and obtaining worker acceptance for Party programs (Harper, 1969: 85-9, Howell, 2008: 846-7). ${ }^{21}$ All unions in China must be incorporated within the official federated union organisation, the ACFTU. It remains illegal to set up a union outside of the official union organization, and those who have attempted to do so have been punished severely (Walder and Gong, 1993, Chan, 1993, China Labour Bulletin, 28 August 2008).

\footnotetext{
${ }^{18}$ Clarke et al., 2004: 239, For example in 2001 the Joint Circular on Promoting Collective Consultation and Collective Contracts mandated the involvement of a range of interested state agencies and enterprise associations in implementing the system of collective contracts throughout the country.

${ }^{19}$ Tripartite Consultation (International Labour Standards) Convention, signed 21 June 1976 ILO Convention No. 144 (entered into force 16 May 1978) <http://www.ilo.org/ilolex/cgi-lex/convde.pl?C144>

${ }^{20}$ See, eg, Shanghai Municipal Human Resources and Social Security Bureau 2008 Notice on Promoting the Work of Collective Wage Consultation 1 April 2008

${ }^{21}$ The dual obligations of the unions under the transmission belt are embodied in the Trade Union Law of the People's Republic of China (1992)] (People's Republic of China) National People's Congress (“Trade Union Law 1992") art 4, 5 and 6, and replicated in the Trade Union Law of the People's Republic of China, (People's Republic of China) National People’s Congress (“Trade Union Law 2001”) arts 4, 5 and 6.
} 
The monopoly enjoyed by the ACFTU over union organization comes at the cost of subordination to the Party in terms of both organization and policy (White et al., 1996: 40-1). Unions thus owe a dual loyalty both to 'safeguard the concrete interests of the Chinese workers' but to do so while 'safeguarding the overall interests of the people throughout the country ... [and to] strive for the realisation of China's socialist modernisation' (ACFTU, 20 September 2007). In the reform era, unions have been responsible for obtaining workers' cooperation in improving productivity and making a positive contribution to economic reform, ${ }^{22}$ often to the detriment of their responsibility to represent workers' interests. Diversification and fragmentation of the workforce and the increasing power of enterprises and management has exacerbated this problem (White et al., 1996: 45-6).

\subsection{Domestic pressures for reform: labour unrest}

This model for regulating industrial relations has individualized both labour contracting and dispute resolution at the expense of collective interest representation. Its focus has been on articulating and enforcing legally mandated labour rights. What is missing is a system for the articulation and negotiation of interests; that is, a system which enables periodic negotiation of wages and conditions. Collective consultation and contracting does not fulfill this role. The overall weakness of the position of workers and accumulated grievances over low wages and the inability to obtain redress for abusive and unlawful employer conduct has inevitably fuelled increasing industrial unrest. Major legislative reforms were passed in 2007 and 2008 to address some of the main weaknesses in the existing legal regulatory regime and to provide better protections for workers' rights (Cooney et al., 2007). These reforms did not seek to change the existing regulatory structure of industrial relations and so paid scant attention to redressing weaknesses in systems of collective consultation and collective contracting.

The onset of the global financial crisis not only challenged implementation of these modest legislative reforms, particularly between the first quarter of 2008 and the third quarter of 2009 (Yang, 14 December 2009), it also highlighted the extent to which China's economic growth had become reliant on exports and had become interdependent with global markets (Yu, 24 January 2010). A 4 trillion yuan stimulus package introduced in November 2008 for the years 2009 and 2010 alleviated the worst of the impacts on China's domestic economy (Fu and Si, 27 November 2008), but also highlighted the need to take further steps to reduce reliance on exports to drive economic growth and to carry out readjustment of China's economy to boost domestic consumption. Programs were put in place at the time to reduce the impact of the global financial crisis on China's enterprises such as: temporarily freezing the minimum wage (Yang, 14 December 2009, Friedman and Lee, 2010: 528, Liu, 2010: 49), strengthening the union's role in assisting enterprises in difficulty to forestall employee layoffs and preserve social stability (Pan, 30 December 2008), and transforming collective contracts into a device for increasing workplace flexibility and risk sharing.

Public attention was focused by a number of well publicized violent mass protests in 2009, such as the protest by workers in July 2009 against the takeover of the Tonghua Iron and Steel Group in Jilin which ended in a senior manager being beaten to death (Canaves, 27 July 2009), a large scale protest against

\footnotetext{
22 Trade Union Law 2001 article 7
} 
job losses at the Baoding Yimian Cotton Mill and the subsequent march of over one thousand workers toward Beijing in April 2009 (IHLO, April 2009), and the strike by taxi drivers in a number of cities from November 2008 (Branigan, 24 November 2008). There were dramatic increases in strikes, street protests, mass petitions and labour related litigation, which in Guangdong accounted for $38 \%$ of all protests in 2008 (No author, 2010). In 2010 the spate of suicides at Foxconn and the protracted strikes at several of Honda's autoparts factories in Guangdong attracted worldwide attention (BBC News, 28 March 2010). The difficulty for the state lies in the fact that the increase in labour disputes, especially large, public protests, not only signals systemic problems with China's industrial relations system, but also raises fears about the potential for this unrest to lead to broader social and political instability (Li, 1999, Chung et al., 2006).

The global financial crisis did not usher in a radical change in industrial relations policy. It did help to focus attention on the need to speed up economic readjustment and marked the heightened political sensitivity to the impacts of industrial disruption on social stability. If anything, the protection of social stability has recently been raised to the highest policy level. A central focus of the 2011 National People's Congress (NPC) meeting was 'stability protection' and 'social management' with allocation of massive funding to support establishment of the institutional infrastructure, including stability preservation committees, to support these programs (Lam, 2011).

The state has adopted a range of strategies to deal with the problems of increasing industrial unrest including law reform to deal with some of the worst failings of the current legal regulatory regime, improving the minimum wage and, of significance for this chapter, re-examining the role that collective consultation and collective contracts might play in promoting industrial stability. The renewed focus on reinvigorating collective consultation must thus be understood in the context of this official preoccupation with controlling social and political instability. It is arguably only one of a wide range of measures being adopted or considered to promote this overall policy objective.

\subsection{Re-examining the role of unions and collective consultation}

In the face of this ongoing unrest, the Party and government have encouraged the unions to take a more active role in protecting workers' rights, if they are not to become completely irrelevant to workers. From the mid 2000s the ACFTU has adopted a range of policies that advocate strengthening their representation and protection of workers' rights (Howell, 2008: 847, Zhu et al., 2011, China Labour Bulletin, 2008) including the Blue Paper on the Role of Chinese Trade Unions in Safeguarding the Legitimate Rights and Interests of the Workers in 2007 (the 'Blue Paper'). ${ }^{23}$. As a way of protecting the rights of workers, the Blue Paper emphasizes expanding collective contracts and improving the

\footnotetext{
${ }^{23}$ In 2004, the Wang Zhaoguo, member of the Political Bureau of the CCP Central Committee, Vice Chairman of the National People's Congress (NPC) Standing Committee, and Chairman of the ACFTU announced the programme: 'Get organized, conscientiously protect rights' (Chang, 2004). At the ACFTU's $15^{\text {th }}$ Congress the following provision was added to article 28: 'Adhere to the path of developing socialist trade unions with Chinese characteristics, adhere to the 'Get Organized and Conscientiously Protect Rights' work plan, put workers first, take the initiative in protecting rights in a scientific way and according to law.' See Wang, 21 October 2008 also Yang, 16 December 2009. The ACFTU also amended the ACFTU Constitution in 2008 to articulate its rights protection policy.
} 
processes of collective consultation, particularly in respect of wages. The rhetoric of 'rights protection', however, must be understood in the limited way in which it is intended; as interconnected with stability maintenance. The ACFTU's interpretation of rights protection is to protect the right of workers to participate in the benefits of economic reform and development for the purpose of promoting stability in labour relations. ${ }^{24}$.

The Party and union focus on industrial stability and their understandings of how stability may be achieved, establish the outer boundaries within which reforms to collective contracting are taking place. The focus is on preventing disputes entirely, or resolving them in the early stages. Stability understood as an absence of disputes imposes limits on the extent to which industrial action taken in pursuit of collective bargaining can be tolerated or accepted. Whilst the ILO advocates collective bargaining as a way of 'stabilizing industrial relations' (ILO, 2010), many in China have argued that collective bargaining would lead to an increase in strikes and other forms of industrial disruption. One economist has even argued that collective wage negotiations will lead to an increase is strikes and be a disaster for industry (Zhang, 1 June 2010).

Against this view is the realization that at present there is no regularized mechanism for negotiation of interest based claims. With the possible exception of a small number of individuals with very strong bargaining power, individual labour contracts generally do not provide an adequate mechanism for negotiation of periodic pay increases or other periodic improvements in working conditions. Since the Ministry of Human Resources and Social Security (MOHRSS) issued the Minimum Wage Regulations in 2004, increasing the minimum wage has been one mechanism used to improve the conditions of China's lowest paid workers, who are often paid at the minimum wage rate. In recent years many governments have significantly increased the minimum wage. Indeed, reform of the wages system was included as a task of the CPC's $12^{\text {th }}$. Five Year Economic and Social Development Plan launched in March 2011. ${ }^{25}$. However, there is doubt as to whether raising the minimum wage can effectively address the problem of labour instability (Su, 21 January 2011). It certainly cannot act as a substitute for negotiation of interest based claims, a function which in theory may be served by collective bargaining. The need to address the causes of industrial unrest has created the space, albeit constrained, for an exploration of the ways in which collective consultation and collective contracts may be reformed to serve this purpose.

\subsection{Reinvigorating collective consultation and contracting - new initiatives}

The system of collective contracts has been in place for a number of years with trade unions authorised to conclude collective contracts with the employer at enterprise level in the 1992 Trade Union Law. ${ }^{26}$.

\footnotetext{
${ }^{24}$ Wang, 2011: 20. Linking rights protection to the primary objective of stability maintenance in this way was articulated in the Harmonious Society policy which was formally adopted at the close of the Sixth Plenary session of the $16^{\text {th }}$ CPC Central Committee meeting on 11 October 2006 in the Resolution on Major Issues Regarding the Building of a Harmonious Socialist Society, announced at <http://www.china.org.cn/english/report/189591.htm>. ${ }^{25}$ Chapter 32 section 1, reproduced at <http://news.sina.com.cn/c/2011-03-17/055622129864.shtml>.

${ }^{26}$ Trade Union Law, Art. 20: Trade unions shall assist and guide workers and staff members in signing labour contracts with enterprises or institutions managed as enterprises. Trade unions shall, on behalf of the workers and staff members, make equal consultations and sign collective contracts with enterprises or institutions under enterprise-style management. The draft collective contracts shall be submitted to the congresses of the workers and staff members or all the workers and staff members for deliberation and approval. When trade unions sign
} 
The system of collective contracts was formally established in articles 33-35 of the PRC Labour Law in 1994, ${ }^{27}$. but it was not until 2004 that detailed provisions governing collective contracts were passed in the Provisions on Collective Contracts. ${ }^{28}$. These provisions continue in effect to the extent they are not superseded by provisions of the 2007 Labour Contract Law which provides an outline regulation of collective contracts. Whilst the primary model of collective consultation and contracting is at enterprise level, article 53 authorises conclusion of industry and regional level collective contracts negotiated at county level. This provision provides legislative authorization for one of the forms of local experimentation primarily in Zhejiang that has been the focus of much laudatory attention; conclusion of industry level collective contracts. This type of collective contract has been used primarily to fix wage rates and to provide for periodic wage increases. This type of collective contracting has been concentrated in sectors such as construction, mining, textiles, food, security, service and the taxi industry, where there is a concentration of small or medium-sized privately owned enterprises, many without enterprise unions, in a particular district (Xinhua Web, 4 June 2010). In these situations, tradebased union associations have been organized to represent workers in the same industry, to negotiate with local employers' associations to fix common wage standards and working conditions (Liu, 2010: 4447).

One of the best known illustrations of this form of collective negotiation is the Wenling model of tripartite collective bargaining in the woolen knitwear industry in Xinhe township, Wenling. The local industry comprises a large number of mostly small-scale family run enterprises. Because of the seasonal nature of the work, employers took a range of measures seeking to ensure workers did not leave during the busy season, including non-payment of wages. This resulted in widespread industrial disruption including strikes, go slows and mass petitioning to higher levels. Collective consultation was initiated as a way of responding to this unrest. A collective agreement was ultimately concluded between the Changyu knitwear industry union and the Xinhe town industry association, which had been established in 2002 ((Wen, 2011: 116-7). The successful conclusion of this agreement depended very much on active support by the Xinhe Party Committee and the local government. This type of industry level agreement has been lauded at top political levels as a model to be adopted nationwide. ${ }^{29}$ This form of collective

collective contracts, trade unions at higher levels shall afford support and assistance to them. If an enterprise infringes upon labor rights and interests of the workers and staff members in violation of the collective contract, the trade union may, according to law, demand the enterprise to assume the responsibilities for its acts; if the disputes arising from the performance of the collective contract fail to be settled through consultations, the trade union may submit them to the labor dispute arbitration bodies for arbitration; if the arbitration bodies refuse to accept the case or the trade union is not satisfied with the arbitral ruling, the trade union may bring the case before a People's Court. ${ }^{27}$ Labour Law article 33 provides: The staff and workers of an enterprise as one party may conclude a collective contract with the enterprise on matters relating to labour remuneration, working hours, rest and vacations, occupational safety and health, and insurance and welfare. The draft collective contract shall be submitted to the congress of the staff and workers, or to all the staff and workers for discussion and adoption. A collective contract shall be concluded by the trade union on behalf of the staff and workers with the enterprise; in an enterprise where the trade union has not yet been set up, such contract shall be also concluded by the representatives elected by the staff and workers with the enterprise.

${ }^{28}$ Passed on 1 May 2004 by the Ministry of Labour and Social Security ('MOLSS') as it then was (now Ministry of Human Resources and Social Security (MOHRSS). These provisions supersede the 1994 Provisions on Collective Contracts and provide the current legal framework for conclusion of collective contracts

${ }^{29}$ In 2007 Wen Jiabao noted that the 'Wenling model can be studied and promoted' (China Labor News Translations, 10 October 2008) In 2006 the ACFTU, MOHRSS the Chinese Enterprises’ Federation and the Chinese 
agreement is expanding, with reports that in January 2010, 200,000 industrial or regional collective contracts and 417,000 collective contracts involving wage collective bargaining covering 51.1 million employees had been concluded (Juan, 2 March 2010). This type of agreement has the advantage of bypassing the enterprise union, or enabling negotiations to take place where there are a large number of non-unionised workplaces. One major attraction for Party and government of this model is that it was seen as being effective in resolving serious problems of labour unrest including strikes and petitioning. Despite the positive evaluation of this form of collective wage negotiations, there is some evidence that the outcomes have not been as good as claimed. Eli Friedman's extensive work on sectoral level collective contracts in nearby Rui'an suggests that neither workers nor individual enterprises had inputs into the negotiation of the collective contract and that the labour disputes the collective agreement had been designed to solve had not in fact been resolved. He also concludes that to the extent industry agreements in Zhejiang have been successful, this success has been heavily dependent upon the particular mode of development in that province. This calls into question the capacity of this model of collective contracting to being extended nationwide (Friedman, 2011).

In Shenzhen and Guangdong senior government officials have been more willing on occasion to use the language of collective bargaining (集体谈判) instead of the more commonly employed term of collective consultation (集体协商).. ${ }^{30}$. Despite some signs of willingness in some regions to reform the existing system of negotiating collective contracts toward permitting more vigorous forms of collective consultation to take place, particularly in Shenzhen and Guangdong, it is far from clear that provincial leaders would be willing to go so far as to allow collective bargaining. There are also signs of resistance to more radical reforms.

In the absence of a more comprehensive national law on collective consultation, some tentative steps have been taken at the local level to legislate for measures to strengthen union responsiveness to the workers they are supposed to represent and to facilitate collective negotiations. ${ }^{31}$. In the Shenzhen regulations for example, these include setting up a system of direct election of union leadership, ${ }^{32}$ and prohibiting the enterprise management personnel including the legal representative, general and deputy general manager, cadres with equivalent positions, responsible people in the personnel department, or any relatives of these categories of person working in the same enterprise from occupying leadership positions in the union (article 11(3)). These provisions are a significant departure

Entrepreneurs' Association jointly issued the Opinion on Developing Regional and Industry Level Collective Consultation Work reproduced at <http://www/gd.lss.gov.cn/ldtzw/zc/flfg/zxfg/t20061025_12690.htm>

${ }^{30}$ In his comments on the Shenzhen Measures on Implementing the PRC Trade Union Law passed in 2008 by the Shenzhen Congress Standing Committee, the head of the Legal Department of the Municipal Union, Zhang Youquan, asserted that the use of the term collective bargaining reflected the objective reality that there is a conflict of interest between labour and capital in Shenzhen. Li et al., 31 July 2008: 5).

${ }^{31}$ Shenzhen Regulations on the Promotion of Harmonious Labour Relations which took effect on 1 November 2008 the 2007 Shanghai Collective Contracts Provisions, 2009 Hainan Collective Contracts Provisions, the Guangdong Guidelines on Enterprise Collective Consultation on Wages passed on 5 August 2010 and the Zhejiang Province Collective Contracts Provisions passed by the Zhejiang Provincial Peoples' Congress to take effect on 1 January 2011 are examples.

32 Shenzhen Measures on Implementing the PRC Trade Union Law art 11(1) which provides that candidates for the positions of union chair and vice chair and standing committee members shall be nominated by union members, approved by the higher level union and subject to direct election by the union general assembly. 
from the weak provisions in the Trade Union Law on management representation in the enterprise union. $^{33}$

Draft local regulations in both Shenzhen, the Shenzhen Labour Relations Collective Consultation Regulations and Guangdong, the Guangdong Regulations on the Democratic Management of Enterprises, propose to go even further to facilitate a more robust form of collective negotiation. The draft Guangdong regulations even suggest that there may be some circumstances where strikes and other forms of industrial action may be permissible in the process of negotiating a collective contract if the employer delays or obstructs wage negotiations (draft 3, article 51). Still, the draft regulations themselves contain provisions indicating that implementation will continue to rely heavily upon support and enforcement by local government agencies. These reform proposals have faced intense opposition and lobbying from Hong Kong, Japanese and Taiwanese industry representatives and as a result the regulations have not yet been passed (Chen, 27 September 2010).

\section{$4 \quad$ Evaluation: possibility for innovation but of what type?}

Whilst these proposed reforms indicate willingness of local governments to facilitate more robust forms of collective negotiation, without a more fundamental change to China's unions, or reforms that enable the enterprise unions to be bypassed in the process of collective bargaining, these reforms will be limited. Whilst international definitions of collective bargaining and its inextricable link with principles of freedom of association are well understood in China, advocacy for the establishment of independent unions remains politically unacceptable. Those advocating reform from within the existing system discuss ways of strengthening union accountability to workers and the centrality of union rights protection work. However, these cannot be seen as radical proposals for reform of the system, as unions in so doing are merely performing the role allocated to it by the Party; protecting rights as a way of protecting stability. Whilst there may be some scope for discussion of the meaning of these terms and the relationship between them, reforms to collective contracting remain bounded by the prohibition on independent labour organizations. As a result, reforms to strengthen collective consultation and collective contracting will continue to rely heavily on the support and participation of local governments and Party organizations. Some of the most recent reforms to strengthen collective consultation have bypassed enterprise unions and break the union monopoly on negotiating collective contracts by giving more direct voice to worker representatives in the process of collective consultation by strengthening the role of the Employee Representative Councils. ${ }^{34}$. Rather than introduce reforms that bring Chinese models of collective consultation closer to the international standards, ongoing reforms have sought to bypass or minimize impediments in the existing industrial landscape. These reforms draw on established regulatory patterns to achieve these objectives; that is, coordinated action by the Party, government, labour departments, courts, and the union hierarchy to achieve these objectives. An examination of the recent innovations in collective contracting such as the Wenling model of industry wide collective

\footnotetext{
${ }^{33}$ Trade Union Law 2001 art 9 merely prohibits close relatives of main management personnel of enterprises from membership of grass-root trade union committees. It does not expressly prohibit managers themselves form membership of the enterprise union committee.

${ }^{34}$ For example the Zhejiang Collective Contracts Provisions and the draft Guangdong Regulations on the Democratic Management of Enterprises the Shanghai Provisions on Employee Representative Councils
} 
consultation reveals that its success depended very much on the initiative and support of the local Party and government.

The tentative steps toward strengthening the processes of collective consultation, whilst framed as 'rights protection', are most readily understood as a way of seeking to reduce labour disputes and as a way of achieving the more modest goal of enabling workers to participate in the benefits of economic and social development to the extent and in the ways determined by Party policy. The willingness to use collective contracts during the global financial crisis as a way of shoring up the profitability of enterprises through temporarily freezing wage rises and introducing risk sharing measures demonstrates that collective contracts are not inevitably understood as a mechanism for improving workers wages and conditions, as they may be harnessed for other purposes when considered necessary. It reveals a particular state-centred view of social justice: one that is provided by the state, in contrast to the more decentred view of social justice advocated by the ILO, which emphasizes workers' agency in negotiating and securing decent working conditions. One of the hazards of a state-centred orientation toward social justice is that increasing worker agency becomes something to be feared as not only disruptive, but also potentially as a threat to political stability. Nor does such an approach promise that the state, in exchange, will either value or protect workers' rights- even if they are defined in a limited way to enable some enjoyment of the fruits of economic reform and national prosperity. Those groups of workers who are not in a strong economic bargaining position have largely been left to the predations of the interests of capital, whilst the state has given priority to GDP growth. Whether the tentative reforms to collective consultation discussed in this chapter mark a significant change in that priority remains to be seen.

\section{References}

ACFTU, (20 September 2007) 'A Brief Introduction of the All-China Federation of Trade Unions'. Alston, Philip, (2004) "Core Labour Standards' and the Transformation of the International Labour Rights Regime' 15, European Journal of International Law, 457-521.

Anonymous, (15 March 2010) 'Perfect the system of collective bargaining: give full play to the role of the unions (健全集体谈判机制 发挥工会作用)', China County Economic News (online) (中国县域社会经济 网), 4.

Anonymous, (30 December 2010) 'Yuji Nianmo Quanguo Guo Guomo Yishang Qiye Laodong Hetong Qianding Lv da $97 \%$ (It is expected that by the end of the year over $97 \%$ of national scale enterprises will have signed labour contracts)'.

BBC News, (28 March 2010) 'Foxconn Suicides: Workers Feel Quite Lonely'.

Berik, Gunseli and van der Meulen Rodgers, Yana, (January 2008) 'The Debate on Labour Standards and International Trade: Lessons from Cambodia and Bangladesh' Working Paper No 2007-03, Department of Economics Working Paper Series University of Utah.

Biddulph, Sarah and Cooney, Sean, (1994) 'Regulation of Trade Unions in the People's Republic of China' 19, Melbourne University Law Review, 253-92.

Branigan, Ta nia (24 November 2008) 'China taxi drivers strike as economic unrest spreads', The Guardian (online).

Canaves, Sky, (27 July 2009) 'Chinese Steelworkers Fight Privatization Effort', Wall Street Journal (online). 
Chan, Anita, (1993) 'Revolution or Corporatism: China's Workers and Trade Unions in Post-Mao China' 29, The Australian Journal of Chinese Affairs, 31-61.

Chan, Anita and Ross, Robert, (2003) 'Racing to the Bottom: International Trade without a Social Clause' 24, Third World Quarterly, 1011-28.

Chang, Gansheng, (2004) 'Zuzhi Qilai, Qieshi Weiquan (Get Organised, Conscientiously Protect Rights) '

11, Gonghui Bolan (Labour Union Expo), 6-7.

Chen, Feng (2010) 'Trade Unions and the Quadripartite Interactions in Strike Settlement in China ' 102, The China Quarterly, 104-24.

Chen, Xiaowei, (27 September 2010) 'The Draft Shenzhen Collective Consultation Regulations: Stop the minimum wage standard becoming the highest (深圳集体协商条例草案：防最低工资标准成 “最 高” )', East Money (online) (东方财富网).

China Labor News Translations, (10 October 2008) 'Collective Wage Consultation: A Breakthrough for Resolving Labor Disputes in Wenling Zhejiang', China Business Report.

China Labour Bulletin, (28 August 2008) 'Founder of Independent Trade Union Released from Prison'. China Labour Bulletin, (2008) 'The Case of China: The Challenge of Labour Unrest in a Communist-run Capitalist Economy'.

Chung, Jae Ho, Lai, Hongyi and Xia, Ming (2006) 'Mounting Challenges to Governance in China: Surveying Collective Protestors, Religions Sects and Criminal Organizations' 56, The China Journal, 1-31.

Clarke, Simon, Lee, Chang-Hee and Li, Qi, (2004) 'Collective Consultation and Industrial Relations in China' 42, British Journal of Industrial Relations, 235-54.

Cooney, Sean, (1999) 'Testing Times for the ILO: Institutional Reform for the New International Political Economy' 20, Comparative Labor Law and Policy Journal, 365-99.

Cooney, Sean, Biddulph, Sarah, Li, Kungang and Zhu, Ying, (2007) 'China's New Labour Contract Law: Responding to the Growing Complexity of Labour Relations in the PRC' 30, University of New South Wales Law Journal, 786-801.

Elliott, Kimberley, (2000) 'The ILO and Enforcement of Core Labor Standards', International Economics Policy Briefs, http://www.iie.com/publications/pb/pb00-6.pdf

Friedman, Eli, (2011) 'Economic Development and Sectoral Unions in China: the cases of Guangdong and Zhejiang', Comparative Chinese Labour Studies Conference, 1-51.

Friedman, Eli and Lee, Ching Kwan, (2010) 'Remaking the World of Chinese Labour: A 30 Year

Retrospective' 48, British Journal of Industrial Relations, 507-33.

Fu, Jing and Si, Tingting, (27 November 2008) 'NDRC reveals details of stimulus package', China Daily. Harper, Paul, (1969) 'The Party and Unions in Communist China' 37, The China Quarterly, 84-119.

Howell, Jude, (2008) 'The All-China Federation of Trade Unions Beyond Reform? Slow March of Direct Elections' 196, The China Quarterly, 845-63.

IHLO, (April 2009) 'Baoding workers' rally: Harbinger of a Long March?'.

IHLO, (February 2009) 'Updates to collective bargaining and collective contracts: New laws - same deal?'. ILO, (2010) 'Collective Bargaining'.

Juan, Shen (ed), (2 March 2010) 'The Majority of Enterprises of Provincial level and above scale have a labour contract signing rate of over $90 \%$ (多数省份规模以上企业劳动合同签订率逾 $90 \%$ )', The

National People's Congress of the People's Republic of China] (online), 《全国人民代表大会》，16-7. Kent, Ann, (2007) Beyond Compliance: China, International Organizations, and Global Security Stanford, Stanford University Press.

Lam, Willy, (2011) 'Beijing's Blueprint for Tackling Mass Incidents and Social Management' 11, China Brief, 3-5.

Li, Ma (ed), (7 October 2008) '1.091 Million Collective Contracts Signed Nationally; 140 Million People Covered', China Network. 
Li, Wei, (1999) 'Ruhe Yufang he Kongzhi Qunzong Jiti Shangfang (How to Prevent and Control the Masses Engaging in Collective Petitioning)', Mishu zhi You (The Secretary's Friend), 34-35.

Lieberwitz, Risa, (2006) 'Linking Trade and Labour Standards: Prioritizing the Right of Association' 38, Cornell International Law Journal, 641-53.

Liu, Mingwei, (2010) 'Union Organizing in China: Still a Monolithic Labor Movement?' 64, Industrial and Labor Relations Review 30-52.

No author, (2010) 'Guangzhou: Disputes between Labour and Capital have Become the Primary Factor Affecting Social Stability (广州: 劳资纠纷成为影响社会稳定第一因素)'.

Pan, Yue, (30 December 2008) ' '大力开展工会与企业、职工的 “共同约定行动” 团结动员广大职 工为促进经济平稳较快发展做贡献 [Vigorously Implement the 'Mutually Agreed Action' between Trade Unions, Enterprises and Employees to promote unity and to mobilize the broad masses of workers to contribute to stable and rapid economic development] ', 《全国人民代表大会》[The National People's Congress of the People's Republic of China] (online).

Sharma, Ruchir (June 20, 2010) "The Post-China World: the end of the boom is now in sight, and the ripple effects of slower growth will span the globe.', Newsweek.

Su, Zhenhua, (21 January 2011) 'Tigao Zuidi Gongzi Bushi 'Wengong' Hao Banfa (Raising the Minimum Wage is not a good way to 'Stabilize the Worforce') 提高最低工资标准不是 “稳工” 好方法', Xinwen Zaobao (Morning News) 新闻晨报, http://finance.ifeng.com/job/xshq/20110121/3269954.shtml. Walder, Andrew and Gong, Xiaoxia, (1993) 'Workers in the Tiananmen Protests: The Politics of the Beijing Workers' Autonomous Federatioin' 29, The Australian Journal of Chinese Affairs, 1-29. Wang, Min, (21 October 2008) 'China's Unions Revise their Constitution to Expand their Protection of the Rights and Interests of Migrant Workers (中国工会修改章程 扩大对农民工权益的保护) ', Xinhua Web (online).

Wang, Quanbao, (2011) 'Chuanguo Zongonghui 'Yi Wequan Lai Weiwen' (ACFTU: Protecting Stability by Protecting Rights)' 4, China Newsweek, 20-21.

Wen, Xiaoyi, (2011) 'Jiti Tanpan de Neibu Guojia Jizhi: Yi Wenling Yangmaoshan Hangye Gongjia Jiti Tanpan Weili (The Internal State Mechanisms in Collective Bargaining: Evidence from the Collective Bargaining by Wenling Sweater Industry (sic))' 1, Shehui (Society), 112-30.

White, Gordon, Howell, Jude and Shang, Xiaoyuan, (1996) In Search of Civil Society: Market Reform and social Change in Contemporary China Oxford, Clarendon Press.

WTO Ministerial Conference, (2001) 'Doha WTO Ministerial 2001: Briefing Notes'.

Xinhua Web, (4 June 2010) ' The ACFTU responds to this reporter's questions on implementation of the 'Rainbow' Programme (全总就实施 “彩虹” 计划答本网记者问)', Xinhua News Agency (online) 《新华 网》.

Yang, Lin, (14 December 2009) '2009 Background to Conflicts Between Labour and Capital: the Global Financial Crisis', Sina 新浪.

Yang, Lin, (16 December 2009) 'Zhuazhu Zhongxin Shen shi Laozi Geju, Xiaochu Laozi MaodunZhe Yinchong, Tiaozheng Laogong Zhengci de Jihui (Seize the opportunity to re-evaluate labour Relations, eliminate potential labour problems, and reformulate labour policy)', Liaowang.

Yu, Yongding, (24 January 2010) 'China's Response to the Global Financial Crisis', East Asia Forum (online).

Zhang, Wuchang, (1 June 2010) 'Gongzi jiti xieshang geng rongyi daozhì bagong shi yanzhong huohai (Collective Wage negotiations are more likely to lead to strikes - it will be a serious disaster) 工资集体协 商更容易导致罢工 是严重祸害'.

Zheng, Guanghuai, (2010) 'Laogong Quanyi yu Anfuxing Guojia- Yi ZhuJiang Sanjjiao Zhou Nongmingong Weili (Workers' Rights and Interests and the Appeasing State- Migrant Workers in the Pearl River Delta Region as an Example)' 5, Kaifang Shidai (Open Times). 
Zhu, Ying, Warner, Malcolm and Feng, Tongqing, (2011) 'Employment relations "with Chinese characteristics": The role of trade unions in China' 150, International Labour Review, 127-43.

ACFTU, (20 September 2007) 'A Brief Introduction of the All-China Federation of Trade Unions'. Alston, Philip, (2004) "Core Labour Standards' and the Transformation of the International Labour Rights Regime' 15, European Journal of International Law, 457-521.

Anonymous, (15 March 2010) 'Perfect the system of collective bargaining: give full play to the role of the unions (健全集体谈判机制 发挥工会作用)', China County Economic News (online)(中国县域社会经济 网), 4.

Anonymous, (30 December 2010) 'Yuji Nianmo Quanguo Guo Guomo Yishang Qiye Laodong Hetong Qianding Lv da $97 \%$ (It is expected that by the end of the year over $97 \%$ of national scale enterprises will have signed labour contracts)'.

BBC News, (28 March 2010) 'Foxconn Suicides: Workers Feel Quite Lonely'.

Berik, Gunseli and van der Meulen Rodgers, Yana, (January 2008) 'The Debate on Labour Standards and International Trade: Lessons from Cambodia and Bangladesh' Working Paper No 2007-03, Department of Economics Working Paper Series University of Utah.

Biddulph, Sarah and Cooney, Sean, (1994) 'Regulation of Trade Unions in the People's Republic of China' 19, Melbourne University Law Review, 253-92.

Branigan, Ta nia (24 November 2008) 'China taxi drivers strike as economic unrest spreads', The Guardian (online).

Canaves, Sky, (27 July 2009) 'Chinese Steelworkers Fight Privatization Effort', Wall Street Journal (online). Chan, Anita, (1993) 'Revolution or Corporatism: China's Workers and Trade Unions in Post-Mao China' 29, The Australian Journal of Chinese Affairs, 31-61.

Chan, Anita and Ross, Robert, (2003) 'Racing to the Bottom: International Trade without a Social Clause' 24, Third World Quarterly, 1011-28.

Chang, Gansheng, (2004) 'Zuzhi Qilai, Qieshi Weiquan (Get Organised, Conscientiously Protect Rights) ' 11, Gonghui Bolan (Labour Union Expo), 6-7.

Chen, Feng (2010) 'Trade Unions and the Quadripartite Interactions in Strike Settlement in China ' 102, The China Quarterly, 104-24.

Chen, Xiaowei, (27 September 2010) 'The Draft Shenzhen Collective Consultation Regulations: Stop the minimum wage standard becoming the highest (深圳集体协商条例草案：防最低工资标准成 “最 高” )', East Money (online) (东方财富网).

China Labor News Translations, (10 October 2008) 'Collective Wage Consultation: A Breakthrough for Resolving Labor Disputes in Wenling Zhejiang', China Business Report.

China Labour Bulletin, (28 August 2008) 'Founder of Independent Trade Union Released from Prison'. China Labour Bulletin, (2008) 'The Case of China: The Challenge of Labour Unrest in a Communist-run Capitalist Economy'.

Chung, Jae Ho, Lai, Hongyi and Xia, Ming (2006) 'Mounting Challenges to Governance in China: Surveying Collective Protestors, Religions Sects and Criminal Organizations' 56, The China Journal, 1-31.

Clarke, Simon, Lee, Chang-Hee and Li, Qi, (2004) 'Collective Consultation and Industrial Relations in China' 42, British Journal of Industrial Relations, 235-54.

Cooney, Sean, (1999) 'Testing Times for the ILO: Institutional Reform for the New International Political Economy' 20, Comparative Labor Law and Policy Journal, 365-99.

Cooney, Sean, Biddulph, Sarah, Li, Kungang and Zhu, Ying, (2007) 'China's New Labour Contract Law: Responding to the Growing Complexity of Labour Relations in the PRC' 30, University of New South Wales Law Journal, 786-801.

Elliott, Kimberley, (2000) 'The ILO and Enforcement of Core Labor Standards', International Economics Policy Briefs, http://www.iie.com/publications/pb/pb00-6.pdf 
Friedman, Eli, (2011) 'Economic Development and Sectoral Unions in China: the cases of Guangdong and Zhejiang', Comparative Chinese Labour Studies Conference, 1-51.

Friedman, Eli and Lee, Ching Kwan, (2010) 'Remaking the World of Chinese Labour: A 30 Year

Retrospective' 48, British Journal of Industrial Relations, 507-33.

Fu, Jing and Si, Tingting, (27 November 2008) 'NDRC reveals details of stimulus package', China Daily.

Harper, Paul, (1969) 'The Party and Unions in Communist China' 37, The China Quarterly, 84-119.

Howell, Jude, (2008) 'The All-China Federation of Trade Unions Beyond Reform? Slow March of Direct Elections' 196, The China Quarterly, 845-63.

IHLO, (April 2009) 'Baoding workers' rally: Harbinger of a Long March?'.

IHLO, (February 2009) 'Updates to collective bargaining and collective contracts: New laws - same deal?'. ILO, (2010) 'Collective Bargaining'.

Juan, Shen (ed), (2 March 2010) 'The Majority of Enterprises of Provincial level and above scale have a labour contract signing rate of over $90 \%$ (多数省份规模以上企业劳动合同签订率逾 $90 \%$ )', The

National People's Congress of the People's Republic of China] (online), 《全国人民代表大会》, 16-7.

Kent, Ann, (2007) Beyond Compliance: China, International Organizations, and Global Security Stanford, Stanford University Press.

Lam, Willy, (2011) 'Beijing's Blueprint for Tackling Mass Incidents and Social Management' 11, China Brief, 3-5.

Li, Ma (ed), (7 October 2008) '1.091 Million Collective Contracts Signed Nationally; 140 Million People Covered', China Network.

$\mathrm{Li}$, Wei, (1999) 'Ruhe Yufang he Kongzhi Qunzong Jiti Shangfang (How to Prevent and Control the Masses Engaging in Collective Petitioning)', Mishu zhi You (The Secretary's Friend), 34-35.

$\mathrm{Li}$, Wei , Chen, Xiaowei, Shi, Xisheng and Liu, Yan, ( 31 July 2008) 'Gonghui Jiang Daibiao Zhigong Jiti Tanpan (The Union to Represent Workers in Collective Bargaining)', Shenzhen Shangbao (Shenzhen Business News), 5.

Lieberwitz, Risa, (2006) 'Linking Trade and Labour Standards: Prioritizing the Right of Association' 38, Cornell International Law Journal, 641-53.

Liu, Mingwei, (2010) 'Union Organizing in China: Still a Monolithic Labor Movement?' 64, Industrial and Labor Relations Review 30-52.

No author, (2010) 'Guangzhou: Disputes between Labour and Capital have Become the Primary Factor Affecting Social Stability (广州: 劳资纠纷成为影响社会稳定第一因素)'.

Pan, Yue, (30 December 2008) ' “大力开展工会与企业、职工的 “共同约定行动” 团结动员广大职

工为促进经济平稳较快发展做贡献 [Vigorously Implement the 'Mutually Agreed Action' between

Trade Unions, Enterprises and Employees to promote unity and to mobilize the broad masses of workers to contribute to stable and rapid economic development] ', 《全国人民代表大会》[The National People's Congress of the People's Republic of China] (online).

Sharma, Ruchir (June 20, 2010) 'The Post-China World: the end of the boom is now in sight, and the ripple effects of slower growth will span the globe.', Newsweek.

Su, Zhenhua, (21 January 2011) 'Tigao Zuidi Gongzi Bushi 'Wengong' Hao Banfa (Raising the Minimum Wage is not a good way to 'Stabilize the Worforce') 提高最低工资标准不是 “稳工” 好方法', Xinwen Zaobao (Morning News) 新闻晨报, http://finance.ifeng.com/job/xshq/20110121/3269954.shtml. Walder, Andrew and Gong, Xiaoxia, (1993) 'Workers in the Tiananmen Protests: The Politics of the Beijing Workers' Autonomous Federatioin' 29, The Australian Journal of Chinese Affairs, 1-29. Wang, Min, (21 October 2008) 'China's Unions Revise their Constitution to Expand their Protection of the Rights and Interests of Migrant Workers (中国工会修改章程 扩大对农民工权益的保护) ', Xinhua Web (online). 
Wang, Quanbao, (2011) 'Chuanguo Zongonghui 'Yi Wequan Lai Weiwen' (ACFTU: Protecting Stability by Protecting Rights)' 4, China Newsweek, 20-21.

Wen, Xiaoyi, (2011) 'Jiti Tanpan de Neibu Guojia Jizhi: Yi Wenling Yangmaoshan Hangye Gongjia Jiti

Tanpan Weili (The Internal State Mechanisms in Collective Bargaining: Evidence from the Collective Bargaining by Wenling Sweater Industry (sic))' 1, Shehui (Society), 112-30.

White, Gordon, Howell, Jude and Shang, Xiaoyuan, (1996) In Search of Civil Society: Market Reform and social Change in Contemporary China Oxford, Clarendon Press.

WTO Ministerial Conference, (2001) 'Doha WTO Ministerial 2001: Briefing Notes'.

Xinhua Web, (4 June 2010) ' The ACFTU responds to this reporter's questions on implementation of the 'Rainbow' Programme (全总就实施 “彩虹” 计划答本网记者问)', Xinhua News Agency (online) 《新华 网》.

Yang, Lin, (14 December 2009) '2009 Background to Conflicts Between Labour and Capital: the Global Financial Crisis', Sina 新浪.

Yang, Lin, (16 December 2009) 'Zhuazhu Zhongxin Shen shi Laozi Geju, Xiaochu Laozi MaodunZhe Yinchong, Tiaozheng Laogong Zhengci de Jihui (Seize the opportunity to re-evaluate labour Relations, eliminate potential labour problems, and reformulate labour policy)', Liaowang.

Yu, Yongding, (24 January 2010) 'China's Response to the Global Financial Crisis', East Asia Forum (online).

Zhang, Wuchang, (1 June 2010) 'Gongzi jiti xieshang geng rongyi daozhì bagong shi yanzhong huohai (Collective Wage negotiations are more likely to lead to strikes - it will be a serious disaster) 工资集体协 商更容易导致罢工 是严重祸害'.

Zheng, Guanghuai, (2010) 'Laogong Quanyi yu Anfuxing Guojia- Yi ZhuJiang Sanjjiao Zhou Nongmingong Weili (Workers' Rights and Interests and the Appeasing State- Migrant Workers in the Pearl River Delta Region as an Example)' 5, Kaifang Shidai (Open Times).

Zhu, Ying, Warner, Malcolm and Feng, Tongqing, (2011) 'Employment relations "with Chinese characteristics": The role of trade unions in China' 150, International Labour Review, 127-43. 


\section{University Library}

\section{- MINERVA \\ A gateway to Melbourne's research publications}

Minerva Access is the Institutional Repository of The University of Melbourne

Author/s:

Biddulph, S

Title:

Structuring China's Engagement with International Human Rights: The Case of Wage Protection Law and Practice

Date:

2017

Citation:

Biddulph, S. (2017). Structuring China's Engagement with International Human Rights: The Case of Wage Protection Law and Practice. Biukovic, L (Ed.). Potter, P (Ed.). Local Engagement with International Economic Law and Human Rights, Local Engagement with International Economic Law and Human Rights, (1), pp.236-263. Edward Elgar Publishing Ltd.

Persistent Link:

http://hdl.handle.net/11343/254295 